\title{
THE DISTRIBUTION OF LEPROSY IN NORTH WEST CHINA
}

ROBB:R'T PFARCl.

The provinces of T'singhai and Kansu are the home of a number of races. The Chinese and Moslems have military and political supremacy throughout the area. The bulk of Tsinghai is populated by Tibetans, whose language and customs differ widely from those of their rulers. In Kansu the Chinese and Moslems predominate. The latter are of different stock from the Chinese, and among themselves own different ancestries and languages, although their religious and military strength is one. There are also a number of aboriginal tribes related to the Mongols. These races tend to live separately, and even in the larger cities it is customary to find the Moslems congregated in one of the suburbs. Chinese is the official language, but a knowledge of the local tongue is necessary if one works in the country among the natives.

The population is largely confined to the river valleys where there is watered ground suitable for raising crops. Between the rivers the mountains are high, and offer only scanty herbage for the grazing of sheep and goats. Northward of a line joining Shunwa, Linhsia, and Lintao the soil is loess. Southward, black earth and limestone rock becomes increasingly evident. In places sandstone and granite appear. At the higher altitudes the valleys broaden out into rolling grasslands which in turn give place to wild rock mountains, I5,000 to 25,000 feet high.

Moslems and Chinese occupy and farm most of the fertile tracts of land. Above them sedentary Tibetans raise a little grain which they barter with the nomad Tibetans of the grasslands for cattle and sheep. Among the sedentary Tibetans are trading posts occupied by Moslems and Chinese merchants. These are invariably situated close to Tibetan monasteries.

The staple item of diet of all except the nomad Tibetans is flour made into a dough with water, cut into strips and boiled. Vegetables are sometimes added to this meal. Coarse bread is baked or steamed, and eaten with boiling water or tea. Meat is eaten by the country Chinese on rare occasions-perhaps once or twice a year. Those living in the cities taste meat ${ }^{\circ}$ more frequently. On the whole, the Moslems eat more meat than do the Chinese, and those in the Linhsia (Hochow) district are said to eat a great deal of meat. The aboriginal tribes live on a diet poorer than that of the Chinese. The Tibetans are different again. The nomads eat vast quantities of meat, raw or partially cooked, and take a little flour mixed with tea and butter. The sedentary 


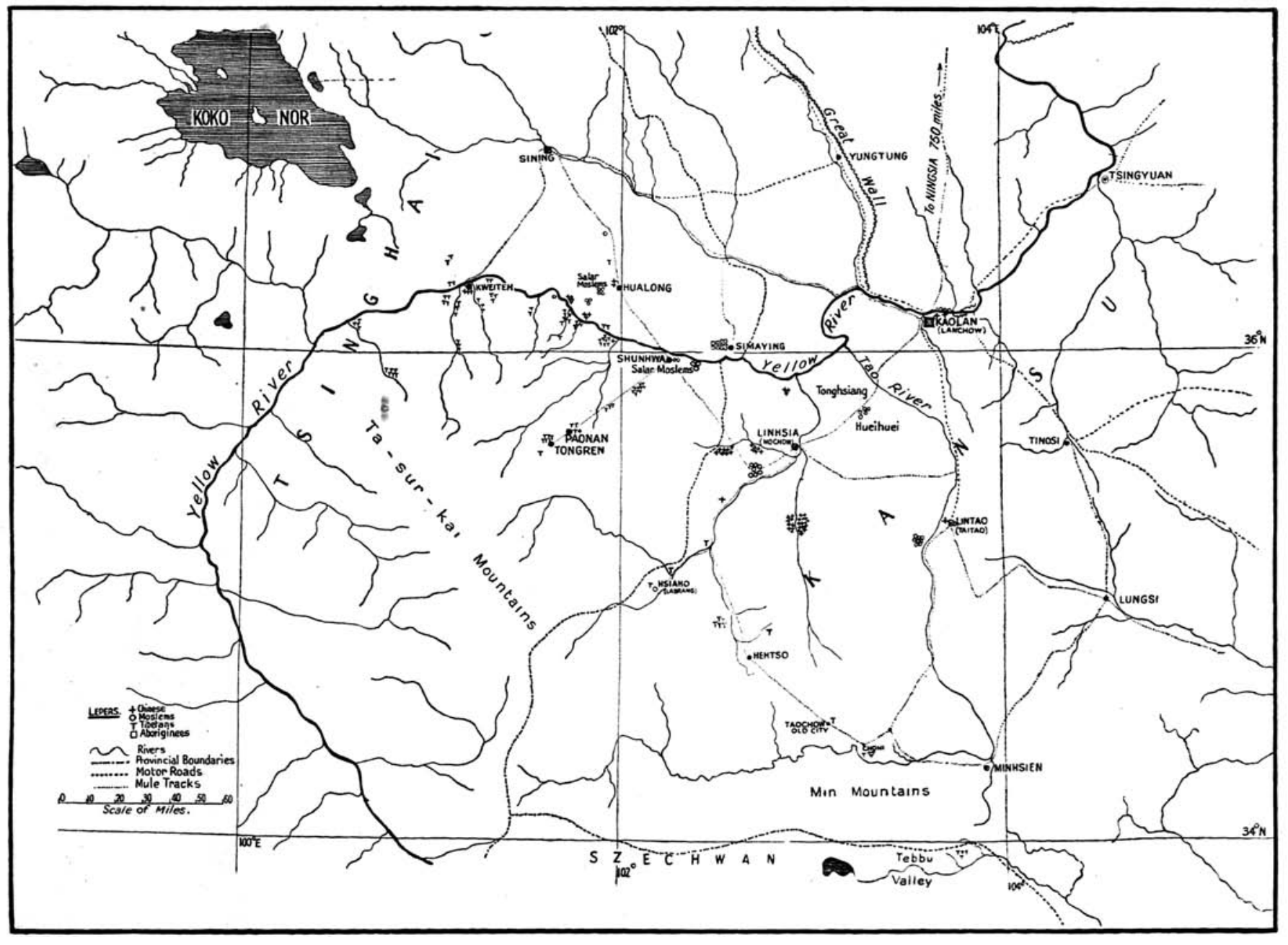

怘

5
0
0
0
0
0
0
0
0
0
0
0 
Tibetans eat more meat than their Chinese neighbours, but are worse off as regards vegetables. In some of the districts at lower altitudes fruit is grown-apples, apricots, peaches and pears. Some of the fruit is good, but the majority is of poor quality. The bulk is sold into the cities.

Clothing is scanty, and the laws of hygiene quite unknown. Housing conditions are poor, and over-crowding is the rule. Syphilis is probably the commonest of all diseases met in this area. It is especially rife among the Tibetans, whose customs allow of a variety of " free love." Adenoma of the thyroid is also very common among the Tibetans, but it is, nevertheless, strictly confined by geographical boundaries. Tuberculosis is found in the cities, but acute specific fevers seem to take the heaviest toll of life.

These remarks apply generally to the tract of country lying south and west of Kaolan (Lanchow). All this is well above 5,000 feet. The grasslands begin between 10,000 and 12,000 feet above sea level. To the east and south of Kaolan, the standards of living are rather higher. There are no aborigines nor Tibetans here. The altitude is generally lower.

Two hundred and seventeen lepers have been treated at the China Inland Mission Hospital at Kaolan during the past fifteen years. The home location of about 200 of these is shown on the accompanying map. This Hospital is the only centre in Tsinghai and Kansu at which lepers receive care and treatment. For the most part of this period no other medical work of western standard was practised in these provinces. These lepers have mostly come from the Yellow River valley, and from the upper sources of the Yangtse, north and east of the Tasurkai mountains. Beyond this range the people are entirely nomad in their habits. No cases have come here, who have contracted the disease in the desert country north of Kaolan. Cases have been seen in Ningsia, about 700 miles north of Kaolan. This is a small area watered by the Yellow River and a system of canals, surrounded by deserts. From the south and east of the province no lepers have come here, but there is said to be a small group near Hweihsien on the Szechwan border.

There is practically no leprosy in the immediate vicinity of Kaolan. We know of one merchant in the city who has the disease, and refuses treatment! He carries on his business without hindrance. A second case has appeared in a labourer who has never been more than twenty miles up or down the river from Kaolan. He knows of no other lepers in his village, which is on an island in the river.

Travelling south from Kaolan, over a stretch of wild unfertile country, one reaches the Tao River, with Lintao (Titao) as the 
chief town. We have received one leper whose home was in this city-the only case we have originating within a city. Ten miles further south from Lintao on the west bank of the river is a district peopled by Moslems, from which eight lepers have come to the Hospital. One of these lepers told us of thirty-eight other lepers known to him, living in his village. The upper part of this valley reaches into Tibetan country. The capital of the principality is Choni, where there is a large monastery, and a very small trading centre. From this place, one Tibetan and three Chinese lepers have come to us. Fifty miles further south, across the Min mountains live the Tebbu tribe of Tibetans. This tribe is partly settled and partly nomadic in its habits-mostly the former. We have four lepers from this very wild tribe, but we are told that leprosy is prevalent in the warmer parts of the valley, the water of which drains into the Yangtze.

Between the lower reaches of the Tao and the Hsia rivers, bounded on the north by the Yellow river, is a tract of loess mountain country inhabited by Moslems, known as the Tonghsiang Hueihuei. These people are of Mongolian descent, and speak a Mongolian dialect. They are farmers, but there are many little market towns. Five lepers have appeared from among this people.

The district surrounding Linhsia (Hochow) is very fertile, and is thickly populated by Moslems. Fifty lepers have come to the Hospital from this district, but only seven of these are Moslemsall from one village, about sixteen miles from the city. The remainder are Chinese farmers who live in the valleys leading out of the main Linhsia valley. Here there is less water, and the soil is less productive. Moslems are generally speaking more wealthy than the Chinese. They have bought out the Chinese from the better land nearer the city-and presumably insured themselves against contracting leprosy! Nearing the grasslands, the Hsia river divides into two, and two trading centres-Labrang and Hehtso-are situated at the river sources. From the valleys around eight Tibetan lepers have come to the Hospital.

Crossing the border into Tsinghai we find a much higher proportion of Tibetans in the population. Of the lepers coming here from Tsinghai, $75 \%$ have been Tibetan. On the border, just north of the Yellow river is a district inhabited by aborigines. These people have a Mongolian ancestry and speech. By religion they follow a lamaist type of Buddhism. They are extremely poor. Famine drove a proportion of them into the Sining district. From among these emigrants, and from the district of Si-ma-ying we have met nine lepers. No case has appeared which is native to Sining.

On the opposite side of the Yellow river is a Moslem popula- 
tion having their centre at Shunhwa. These Moslems are not Chinese, but immigrants from Samarkand, and speak a corrupted form of Turkish. They are known as Salar Moslems. Five Salar Moslem lepers have been treated here. A little higher up the river, on the northern bank is another group of Salar Moslems. Racially they are descended from the Tibetans, but they have embraced the language, speech and customs of the true Salars. They are a very wild people. Eight lepers have come to the Hospital from this district. Other Chinese and Tibetan lepers have also come from this part of the country.

Between Shunhwa and Tongren the valleys support a population of sedentary Tibetans, from among whom we have met twenty lepers. Leprosy is said to be quite common in this area.

Forty miles higher up the river from Shunwa is a fertile stretch of valley known as Shui-ti-chüan. Many tributaries enter the river from the mountains on its south bank. This land is farmed by sedentary Tibetans of a very independent nature, over whom the Chinese have only nominal control. This district has sent us eleven Tibetan lepers.

The Yellow river leaves this region through a long and impassable gorge, and above is a similar gorge descending from another stretch of fertile valley having Kweiteh as its political and civic centre. Three Chinese lepers have homes in the immediate vicinity of Kweiteh, but from the surrounding valleys we have met twenty-five Tibetan lepers. Leprosy is well recognised, at least in its grosser forms by these people. In one of the valleys south of Kweiteh is a deserted village. A new village was built on the opposite bank of the river because of the prevalence of leprosy in the first village. Already two cases of leprosy have been recognised in the new village!

Above these valleys around Kweiteh the altitude forbids cultivation of the land, and the hills support only nomad Tibetans and their flocks. We have only one leper from a nomad tribe. $\mathrm{He}$ is a priest, and although his disease appeared while he was living as a nomad, it is possible that he contracted the infection in some monastery where he was studying.

Six other lepers have appeared here from other provincesone from Anhwei, one from Hunan, who are both well educated men. There are two other ordinary Chinese from eastern Szechwan, one Tibetan from the Szechwan border, and two from an aboriginal tribe-the Kiarung-living in western Szechwan.

The clinical condition of 126 of these lepers is known. In the table following they are classified according to the nomenclature of the Cairo Conference of 1938. The figures in brackets are percentages. 


\begin{tabular}{|c|c|c|c|c|}
\hline District & & Neural & Lepromatous & Total \\
\hline Hochow (Linhsia). & $\cdots$ & I I (30.4) & $26(60.6)$ & $37(29 \cdot 4)$ \\
\hline Labrang $\quad \ldots$. & $\cdots$ & $4(57 \cdot 1)$ & $3(42.9)$ & $7(5.6)$ \\
\hline $\begin{array}{l}\text { Titao (Lintao) } \\
\text { and southwards }\end{array}$ & $\cdots$ & $5(38.5)$ & $8(61.5)$ & I3 ( 10.3$)$ \\
\hline Si-Ma-Ying $\ldots$ & $\ldots$ & $3(50.0)$ & $3(50.0)$ & $6(4.7)$ \\
\hline Hualong $\quad \ldots$ & ... & $5(4 \mathrm{I} \cdot 7)$ & $7(58.3)$ & I2 $(9.9)$ \\
\hline Hsuinhua $\quad \ldots \quad$. & $\cdots$ & $3(33 \cdot 3)$ & $6(66.7)$ & $9(7.1)$ \\
\hline Paonan and Tongre & & $8(72.7)$ & $3(27 \cdot 3)$ & II $(8.7)$ \\
\hline Kweiteh $\quad \ldots \quad$. & $\ldots$ & I6 $(5+6)$ & I $5(48.4)$ & 3 I $(24 \cdot 3)$ \\
\hline Total & $\cdots$ & $55(43 \cdot 7)$ & $7 \mathrm{I}(56.3)$ & $126(100.0)$ \\
\hline
\end{tabular}

Divided according to races the figures appear thus :-

$\begin{array}{lllrrrr}\text { Chinese } & \ldots & \ldots & \text { I5 }(44.1) & \text { I9 }(55.9) & 34(27.0) \\ \text { Moslems } & \ldots & \ldots & 4(\text { I } 7.4) & \text { I } 9(82.6) & 23(\text { I } 8.2) \\ \text { Aborigines } & \ldots & \ldots & 3(37.5) & 5(62.5) & 8(6.4) \\ \text { Tibetans } & \ldots & \ldots & 33(54.1) & 28(45.9) & 6 \text { I }(48.4) \\ \quad \text { Total } & \ldots & \ldots & 55(43.7) & 7 \text { I }(56.3) & \text { I26( IOO.0) }\end{array}$

This distribution, expressed geographically or racially may not represent the true state of affairs. Generally speaking the Tibetans come greater distances. Lepromatous cases being more sick, are less likely to come. These figures confirm the general impression that leprosy is more severe among the Chinese and Moslems, than among the Tibetans.

We gladly acknowledge the help and advice that has been given to us, while writing this account, by our friends of the Christian and Missionary Alliance, who work among the people of whom we write. 